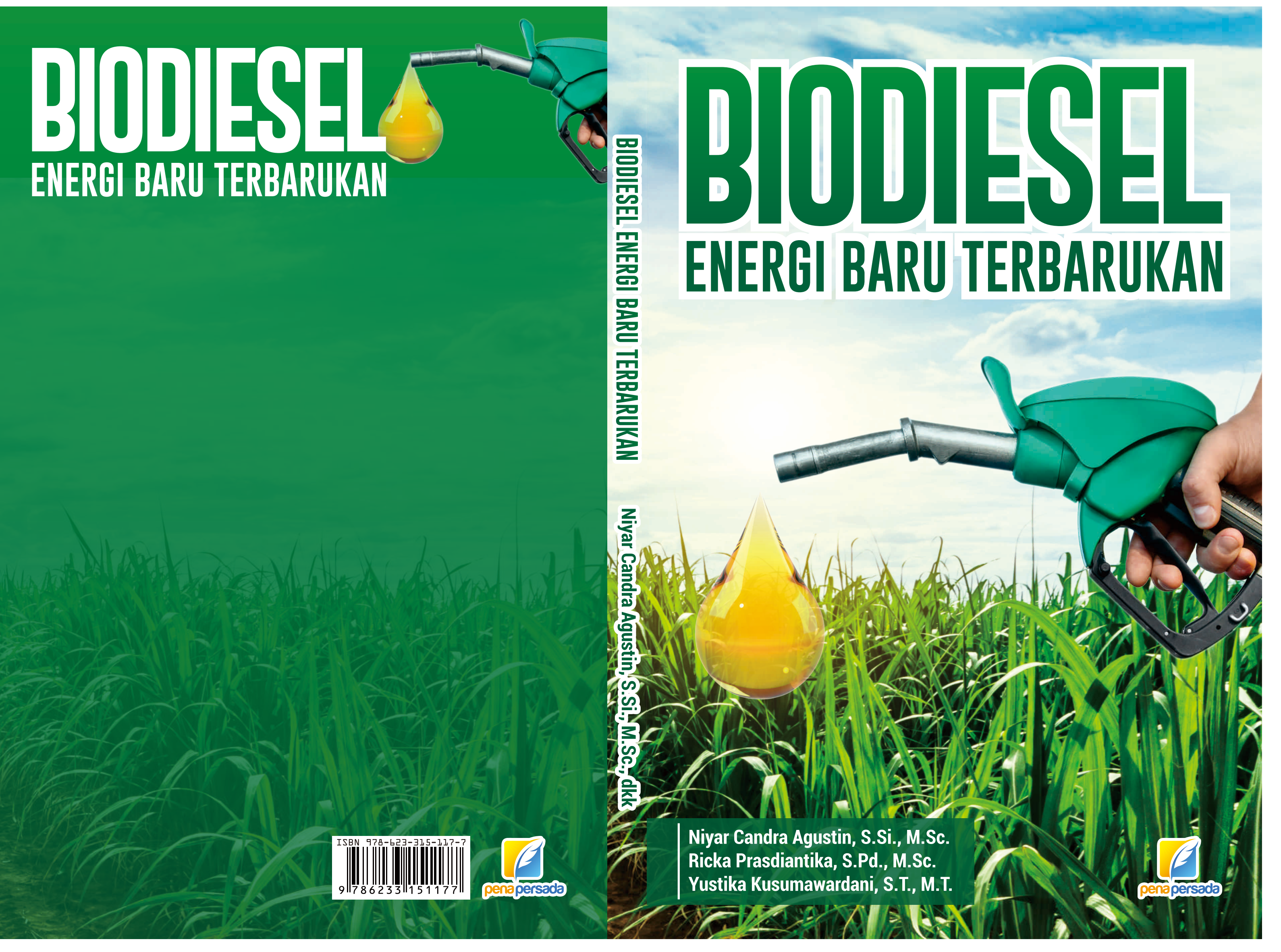




\section{BIODIESEL \\ ENERGI BARU TERBARUKAN}

NIYAR CANDRA AGUSTIN, S.Si., M.Sc.

RICKA PRASDIANTIKA, S.Pd., M.Sc.

YUSTIKA KUSUMAWARDANI, S.T., M.T.

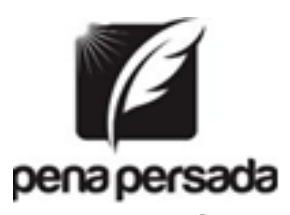

CV. PENA PERSADA 


\section{BIODIESEL \\ ENERGI BARU TERBARUKAN}

Penulis :

Niyar Candra Agustin, S.Si., M.Sc.

Ricka Prasdiantika, S.Pd., M.Sc.

Yustika Kusumawardani, S.T., M.T.

Editor:

Muhamad Imam Syairozi

ISBN : 978-623-315-117-7

Design Cover :

Retnani Nur Briliant

Layout :

Hasnah Aulia

Penerbit CV. Pena Persada

Redaksi :

Jl. Gerilya No. 292 Purwokerto Selatan, Kab. Banyumas Jawa

Tengah

Email : penerbit.penapersada@gmail.com

Website : penapersada.com

Phone : (0281) 7771388

Anggota IKAPI

All right reserved

Cetakan pertama : 2020

Hak cipta dilindungi oleh undang-undang.

Dilarang memperbanyak buku ini dalam bentuk dan cara apapun tanpa ijin penerbit 


\section{UU NO 28 TAHUN 2014 TENTANG HAK CIPTA}

\section{Fungsi dan sifat hak cipta Pasal 4}

Hak Cipta sebagaimana dimaksud dalam Pasal 3 huruf a merupakan hak eksklusif yang terdiri atas hak moral dan hak ekonomi.

\section{Pembatasan Pelindungan Pasal 26}

Ketentuan sebagaimana dimaksud dalam Pasal 23, Pasal 24, dan Pasal 25 tidak berlaku terhadap:

i. penggunaan kutipan singkat Ciptaan dan/atau produk Hak Terkait untuk pelaporan peristiwa aktual yang ditujukan hanya untuk keperluan penyediaan informasi aktual;

ii. Penggandaan Ciptaan dan/atau produk Hak Terkait hanya untuk kepentingan penelitian ilmu pengetahuan;

iii. Penggandaan Ciptaan dan/atau produk Hak Terkait hanya untuk keperluan pengajaran, kecuali pertunjukan dan Fonogram yang telah dilakukan Pengumuman sebagai bahan ajar; dan

iv. penggunaan untuk kepentingan pendidikan dan pengembangan ilmu pengetahuan yang memungkinkan suatu Ciptaan dan/atau produk Hak Terkait dapat digunakan tanpa izin Pelaku Pertunjukan, Produser Fonogram, atau Lembaga Penyiaran.

\section{Sanksi Pelanggaran Pasal 113}

1. Setiap Orang yang dengan tanpa hak melakukan pelanggaran hak ekonomi sebagaimana dimaksud dalam Pasal 9 ayat (1) huruf i untuk Penggunaan Secara Komersial dipidana dengan pidana penjara paling lama 1 (satu) tahun dan/atau pidana denda paling banyak Rp100.000.000 (seratus juta rupiah).

2. Setiap Orang yang dengan tanpa hak dan/atau tanpa izin Pencipta atau pemegang Hak Cipta melakukan pelanggaran hak ekonomi Pencipta sebagaimana dimaksud dalam Pasal 9 ayat (1) huruf $c$, huruf d, huruf $f$, dan/atau huruf h untuk Penggunaan Secara Komersial dipidana dengan pidana penjara paling lama 3 (tiga) tahun dan/atau pidana denda paling banyak Rp500.000.000,00 (lima ratus juta rupiah). 


\section{KATA PENGANTAR}

Puji syukur kehadirat Allah SWT atas limpahan rahmat dan karuniaNya sehingga Buku Ajar dengan judul "Biodesel Energi Baru Terbarukan" dapat terselesaikan dengan baik. Buku Ajar ini disusun bagi mahasiswa Program Studi DIII Teknik Kimia Universitas Pandanaran untuk membantu Mahasiswa dalam mempelajari materi Biodiesel.

Terimakasih disampaikan kepada Direktur Riset dan Pengabdian Masyarakat atas pendanaan Penelitian Dosen Pemula (PDP) Tahun Pelaksanaan 2020 dengan Nomor Kontrak: $\quad$ 011/LL6/PG/SP2H/PENELITIAN/2020. Terimakasih juga disampaikan kepada Universitas Pandanaran dan LPPM (Lembaga Penelitian dan Pengabdian Masyarakat) Universitas Pandanaran atas segala fasilitas serta kepada seluruh pihak yang telah berkontribusi dalam penyelesaian buku ini.

Penulis menyadari masih terdapat kekurangan dalam buku ini. Oleh karena itu saran terhadap penyempurnaan buku ini sangat penulis harapkan. Semoga buku ini dapat member manfaat bagi Mahasiswa Program Studi DIII Teknik Kimia, serta semua pihak yang membutuhkan.

Penulis 


\section{DAFTAR ISI}

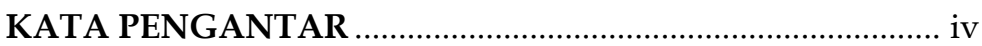

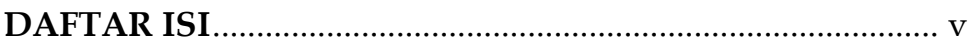

BAB I BIODIESEL

A. Capaian Pembelajaran ....................................................... 1

B. Sejarah Biodesel ........................................................... 1

C. Pengertian Biodiesel ....................................................... 3

D. Perkembangan Biodiesel di Indonesia .............................. 3

E. Teknik Produksi Biodiesel .................................................. 7

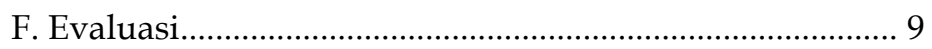

BAB II KLASIFIKASI DAN KARAKTERISTIK BIODIESEL

A.Capaian Pembelajaran .................................................. 10

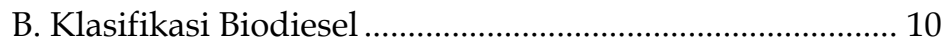

C. Kualitas Biodiesel ........................................................... 13

D. Karakteristik Biodiesel.......................................................... 14

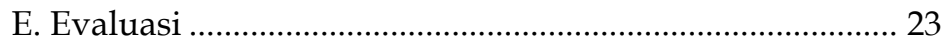

BAB III BAHAN BAKU PEMBUATAN BIODIESEL

A. Capaian Pembelajaran ……............................................. 24

B. Bahan Baku Pembuatan Biodiesel ..................................... 24

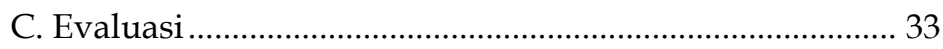

BAB IV PEMBUATAN BIODIESEL

A. Capaian Pembelajaran. ..................................................... 34

B. Bahan Pembuatan Biodiesel .............................................. 34

C. Peralatan dalam Pembuatan Biodiesel. ............................ 35

D. Prosedur Kerja Pembuatan Biodiesel. .............................. 37

E. Reaksi Esterifikasi dalam Pembuatan Biodeiesel ............ 39

F. Reaksi Transesterifikasi dalam Pembuatan Biodiesel ..... 40

G. Penggunaan Microwave pada Pembuatan Biodiesel ..... 42

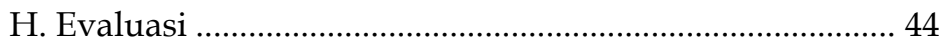

\section{BAB V KARAKTERISASI BIODIESEL}

A. Capaian Pembelajaran. ...................................................... 45

B. Tujuan Karakterisasi Biodiesel............................................. 45

C. Karakterisasi Biodiesel dengan Gas ChromatographyMass Spectroscopy (GC-MS) ............................................. 45

D. Karakterisasi Biodiesel dengan Hidrogen-1 Nuclear Magnetic Resonance (1H-NMR) ...................................... 49 
E. Karakterisasi Biodiesel dengan spektrofotometer Fourier Transform Infra Red (FT-IR)................................ 51

F. Uji kelayakan biodiesel dengan metode ASTM ............... 52

G. Uji kelayakan biodiesel dengan metode ASTM ............... 56

\section{BAB VI FAKTOR-FAKTOR YANG MEMPENGARUHI}

\section{HASIL BIODIESEL}

A. Capaian Pembelajaran. ....................................................... 57

B. Pengaruh perbandingan minyak dengan metanol (alkohol) 57

C. Pengaruh waktu reaksi ......................................................... 58

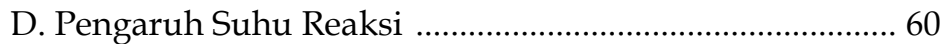

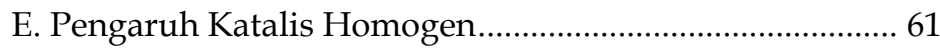

F. Pengaruh Katalis Heterorgen ..................................................... 62

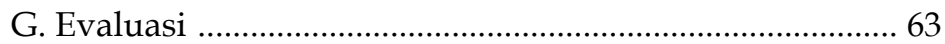

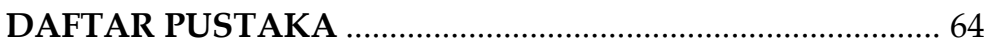

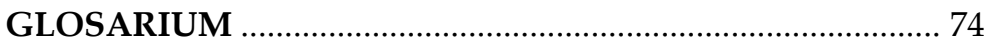

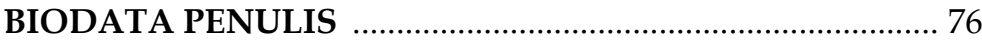




\section{BAB I \\ BIODIESEL}

\section{A. Capaian Pembelajaran}

Setelah mempelajari bab ini, diharapkan mahasiswa dapat mengetahui dan menjelaskan tentang sejarah biodiesel, pengertian biodiesel, perkembangan biodiesel di Indonesia, dan teknik produksi biodiesel.

\section{B. Sejarah Biodesel}

Rudolf Diesel mendesain mesin diesel (compression ignition) yaitu sebuah mesin yang digunakan untuk menjalankan banyak bahan bakar termasuk batu-bara yang tersuspensi dalam air, minyak mineral berat, dan minyak nabati. Eksperimen mesin diesel pertama Rudolf Diesel mengalami kegagalan besar. Pada tahun 1900 Rudolf Diesel menunjukkan mesinnya pada Pameran Dunia di Paris dengan menggunakan 100\% minyak kacang tanah (Pasific Biodiesel, 2017). Pada tahun 1911, Diesel menyatakan: bahwa mesin diesel dapat diumpankan dengan minyak nabati dan akan sangat membantu dalam perkembangan pertanian negara-negara yang menggunakanya (Mishra dan Goswami, 2017)

Pada tahun 1912, Rudolf Diesel mengatakan bahwa penggunaan minyak nabati untuk bahan bakar mesin mungkin pada saat ini tidak tampak signifikan. Namun penggunaan minyak nabati akan menjadi sama penting seperti penggunaan minyak bumi dan produk batu bara pada saat ini. Rudolf Diesel meninggal pada tahun 1913. Mesinnya kemudian dimodifikasi untuk bekerja dengan bahan bakar minyak bumi, yang saat ini dikenal sebagai 'diesel'.

Ide dari Rudolf Diesel tentang pertanian dan penemuannya memberikan pengetahuan dasar bagi masyarakat untuk mendorong penelitian tentang bahan 
bakar yang bersih, terbarukan, dengan bahan baku yang dapat ditanam secara lokal (Owolabi dkk., 2012). Pada situasi darurat (tahun 1930-an dan 1940-an), minyak nabati digunakan sebagai pengganti bahan bakar diesel (Ma dan Hanna, 1999). Saat ini, negara-negara beralih menggunakan biodiesel karena sumber terbarukan dan pengurangan polusi (Owolabi dkk., 2012).

Di Prancis, uji coba pertama dengan minyak nabati metil dan etil ester dilakukan pada tahun 1940. Pada saat yang sama, Ilmuwan Belgia menggunakan minyak sawit etil ester sebagai bahan bakar untuk kendaraan bus. Penelitian tentang biodiesel berjalan lambat sampai akhir 1970-an dan awal 1980-an. Ketika kekhawatiran tentang harga minyak bumi yang semakin tinggi, memunculkan motivasi eksperimen ekstensif dengan menggunakan lemak dan minyak sebagai bahan bakar alternatif (Balat dan Balat, 2008; Friedrich, 2004).

Biodiesel juga dikenal sebagai mono alkyl ester, yang kemudian mulai diproduksi secara luas pada awal 1990-an dan sejak itu produksi terus meningkat. Di UE, biodiesel dipromosikan pada tahun 1980-an sebagai sarana untuk mencegah penurunan produksi bahan bakar dan menanggapi peningkatan tingkat permintaan energi, yang mulai dikembangkan secara luas pada paruh kedua tahun 1990-an (Dufey, 2006). Produksi biodiesel merupakan bidang penelitian dan teknologi terkini bagi para peneliti karena peningkatan permintaan minyak bumi dan memiliki banyak keuntungan bagi lingkungan. Metode produksi biodiesel yang paling umum dan efektif adalah transesterifikasi minyak nabati dan lemak hewani. Pada dasarnya metode tersebut bukan merupakan metode yang baru. Metode tersebut telah disajikan pada tahun 1853 oleh Duffy dan Patrick. Sejak saat itu, banyak penelitian telah dilakukan dengan menggunakan sumber minyak yang berbeda-beda (Balat dan Balat, 2008). 


\section{Pengertian Biodiesel}

Biodiesel atau Fatty Acid Methyl Ester (FAME) merupakan bahan bakar alternatif pengganti minyak fosil (minyak diesel) atau bioenergi yang dibuat dari minyak nabati maupun hewani. Minyak nabati sebagai sumber utama biodiesel dapat didaparkan dari berbagai macam jenis tumbuhan-tumbuhan yang tergantung pada sumber daya utama dari suatu tempat atau negara (Hendra dkk., 2018).

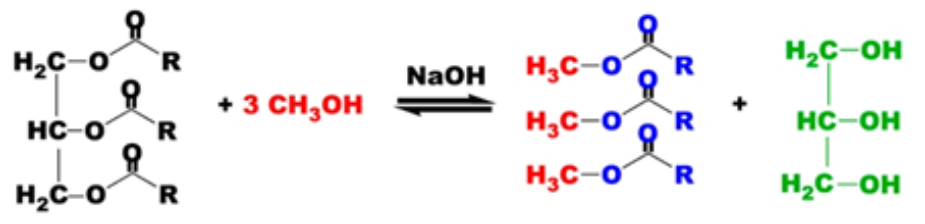

Trigliserida 3 Molekul Metil Ester Gliserol

Gambar 1.1 Transesterifikasi Trigliserida dengan metanol

Pada Tahun 1853, ahli kimia Irlandia Patrick dan Duffy melaporkan hasil transesterifikasi minyak seperti yang terlihat pada Gambar 1.1. Transesterifikasi merupakan reaksi penting dalam industri tidak hanya untuk biodiesel, tetapi sangat penting untuk produksi berbagai produk rumah tangga, sabun, dan deterjen. Semua biodiesel di seluruh dunia diproduksi melalui proses ini (Huang dkk., 2012; Pinto dkk., 2005; Clark dkk., 2012)

Trigliserida adalah molekul dengan satu gugus kepala molekul gliserol dan tiga asam lemak terikat pada tiga gugus hidroksil. Secara umum, karakteristik lemak ditentukan oleh bahan kimianya sifat asam lemak yang menempel pada gliserol. Minyak nabati dan kacangkacangan sebagian besar mengandung triasil gliserol atau trigliserida, itulah sebabnya sering menjadi prekursor untuk biodiesel (Behzadi dan Farid, 2007)

\section{Perkembangan Biodiesel di Indonesia}

Berawal dari krisis energi yang terjadi dan semakin berkurangnya cadangan minyak bumi di Indonesia. 
Pemerintah telah mengeluarkan mandatori dan Peraturan Presiden Republik Indonesia Nomor 5 Tahun 2006 tentang Kebijakan Energi Nasional untuk mewujudkan optimalisasi penyediaan bahan bakar dengan berbasis Energi Baru Terbarukan (EBT) yang mana di antaranya meningkatkan penggunaan bahan bakar energi nabati (biofuel) yaitu biodiesel dan bioetanol (Hendra dkk., 2018).

Selain itu adanya Undang-Undang Republik Indonesia Nomor 30 Tahun 2007 tentang Energi yang memuat penyediaan energi baru dan terbarukan, yang wajib ditingkatkan oleh pemerintah baik pusat maupun daerah sesuai dengan kewenangannya. Peraturan Presiden Republik Indonesia Nomor 5 Tahun 2006 disebutkan bahwa pengembangan biodiesel akan dilaksanakan selama 25 tahun yang dimulai tahun 2004 sebagai tahun persiapan dan pelaksanaannya baru dimulai pada tahun 2015 .

Terdapat tiga fase pengembangan biodiesel. Fase pertama (2005-2010) disepakati minimum 2\% atau 720.000 kilo Liter biodiesel untuk memenuhi kebutuhan minyak nasional dengan produk yang berasal dari minyak jarak dan kelapa sawit. Pada Tahun 2006 Indonesia berhasil memproduksi 44 ribu ton biodiesel, tahun 2008 produksinya mencapai 630 ribu kilo Liter.

Fase kedua (2011-2015) dengan sumber bahan baku biodiesel menggunakan tumbuhan lain sebagai bahan mentah. Selanjutnya pembangunan pabrik berskala komersial dengan kapasitas 30.000-100.000 ton per tahun. Hal ini diharapkan mampu memenuhi 3\% dari konsumsi diesel, ekuivalen dengan 1,5 juta kilo Liter.

Pada fase ketiga (2016-2025), diharapkan teknologi pembuatan biodiesel sudah mencapai level high performance dengan angka setan yang tinggi dan casting point yang rendah, dan diharapkan dapat memenuhi 5\% dari kebutuhan nasional atau 4,7 juta kilo Liter. Pada Tahun 2017 produksi biodiesel sudah mencapai 2,6 juta kilo liter dan masih akan terus meningkat dan berkembang mengingat penggunaan bahan bakar minyak solar yang masih tinggi 
yaitu $40 \%$ dan $74 \%$ adalah penggunaan untuk PLTD (GAPKI, 2017).

Keberhasilan peningkatan produksi biodiesel tersebut tidak terlepas dari arah kebijakan sector energi melalui mandatori Kementerian ESDM yang mengedepankan pengembangan dan pemanfaatan energi baru terbarukan yang salah satunya adalah Bahan Bakar Nabati (BBN). Guna mendukung terlaksananya program tersebut dikeluarkan Instruksi Presiden Republik Indonesia Nomor 1 Tahun 2006 tentang Penyediaan dan Pemanfaatan Bahan Bakar Nabati sebagai Bahan Bakar Lain.

Komitmen untuk mewujudkan kebijakan mandatori pemanfaatan BBN, Kementerian ESDM menerbitkan Peraturan Menteri ESDM Republik Indonesia Nomor 32 tahun 2008 tentang Penyediaan, Pemanfaatan dan Tata Niaga Bahan Bakar Nabati (Biofuel). Sebagai Bahan Bakar Lain, yang isinya memuat aturan sektor transportasi, industri dan pembangkit listrik diwajibkan untuk menyubstitusi bahan bakar fosil dengan BBN pada persentase tertentu dan bertahap (GAPKI, 2017).

Sejak 1 September 2013, mandatori pemanfaatan biodiesel ditingkatkan menjadi sebesar 10 persen (B10) dari sebelumnya yaitu sebesar 7,5\% (B7,5). Dengan kebijakan tersebut, realisasi implementasi mandatori biodiesel di tahun 2014 mencapai 1,84 juta kilo liter (KL) atau mengalami peningkatan sebesar $75 \%$ dibandingkan capaian mandatori biodiesel tahun 2013.

Pemanfaatan biodiesel yang dicampurkan ke dalam Jenis Bahan Bakar Minyak Tertentu (JBT) menjadi penyumbang utama dalam peningkatan capaian tersebut yaitu sebesar 1,16 juta KL (setara dengan $62,7 \%$ dari total capaian tahun 2014). Berikutnya pada tahun 2015, pemerintah menerbitkan 6 (enam) paket kebijakan yang salah satunya adalah peningkatan kewajiban pencampuran biodiesel 15 persen (B15). Kebijakan pemanfaatan B15 dapat menyerap produksi biodiesel dalam negeri sebesar 5,3 juta kilo liter (KL) (setara dengan 4,8 juta ton Crude Palm Oil 
(CPO) dan memberikan penghematan devisa sebesar US\$ 2,54 miliar dari pengurangan impor BBM (ESDM, 2015). Perkembangan produksi dan konsumsi biodiesel Indonesia dapat dilihat pada Tabel 1.1 berikut.

\section{Tabel 1.1}

Perkembangan produksi dan konsumsi biodiesel Indonesia x1000 kilo liter (GAPKI, 2017)

\begin{tabular}{|l|l|l|l|l|l|l|l|l|l|l|}
\hline Tahun & 2008 & 2009 & 2010 & 2011 & 2012 & 2013 & 2014 & 2015 & 2016 & 2017 \\
\hline Produksi & 630 & 330 & 740 & 1800 & 2200 & 2800 & 3000 & 1180 & 2450 & 2600 \\
\hline Konsumsi & 23 & 60 & 220 & 358 & 670 & 1048 & 1600 & 860 & 2250 & 2400 \\
\hline Impor & 0 & 0 & 0 & 0 & 0 & 0 & 0 & 0 & 0 & 0 \\
\hline Ekspor & 610 & 204 & 563 & 1440 & 1515 & 1800 & 1350 & 343 & 200 & 100 \\
\hline
\end{tabular}

Tabel 1.1 menunjukkan produksi pada tahun 2008 adalah sebesar 630.000 kilo liter dengan konsumsi hanya 23.000 kilo liter, sisanya sebesar 610.000 kilo liter masuk pasar ekspor. Produksi biodiesel sempat mengalami penurunan pada tahun 2009 yang hanya mencapai 330.000 kilo liter, selanjutnya terus meningkat dan mencapai puncak produksi pada tahun 2014 yang mencapai 3.000.000 kilo liter. Dari sisi konsumsi dalam negeri terus mengalami peningkatan dari hanya 23.000 kilo liter di tahun 2008, meningkat menjadi 2.400 .000 kilo liter (2,4 juta ton) di tahun 2017.

Untuk pemenuhan pasokan biodiesel ke PT. Pertamina sebagai pihak pendistribusi bahan bakar minyak nasional, saat ini terdapat 20 perusahaan pemasok biodiesel ke PT. Pertamina (Tabel 1.2) untuk kemudian disalurkan ke SPBU di seluruh Indonesia dengan nama biosolar (Kepmen ESDM, 2017) 
Tabel 1.2 Perusahaan pemasok biodiesel ke PT. Pertamina (Kepmen ESDM, 2017)

\begin{tabular}{|l|l|c|}
\hline No & Perusahaan & $\begin{array}{c}\text { Jumlah Pasokan (kilo } \\
\text { liter) }\end{array}$ \\
\hline 1 & PT. Wilmar Nabati Indonesia & 192.460 \\
\hline 2 & PT. Wilmar Bioenergi Indonesia & 192.000 \\
\hline 3 & PT. Musim Mas & 160.300 \\
\hline 4 & PT. Bayas Biofuels & 104.301 \\
\hline 5 & PT. Cemerlang Energi Perkasa & 83.441 \\
\hline 6 & PT. LDC Indonesia & 57.589 \\
\hline 7 & PT. Multi Nabati Sulawesi & 57.574 \\
\hline 8 & PT. Sinarmas Bio Energy & 54.648 \\
\hline 9 & PT. Intibenua Perkasatama & 53.541 \\
\hline 10 & PT. Permata Hijau Palm Oleo & 50.482 \\
\hline 11 & PT. Dabi Biofuels & 50.064 \\
\hline 12 & PT. Kutai Refinery Nusantara & 50.060 \\
\hline 13 & PT. Tunas Baru Lampung & 47.794 \\
\hline 14 & PT. SMART Tbk & 46.998 \\
\hline 15 & PT. Sukajadi Sawit Mekar & 36.505 \\
\hline 16 & $\begin{array}{l}\text { PT. Batara Elok Semester } \\
\text { Terpadu }\end{array}$ \\
\hline 17 & PT. Ciliandra Perkasa & 34.767 \\
\hline 18 & PT. Darmex Biofuels & 34.767 \\
\hline 19 & PT. Pelita Agung Agriindustri & 34.767 \\
\hline 20 & PT. Energi Baharu Lestari & 27.814 \\
\hline & \multicolumn{2}{|l}{13.907} \\
\hline
\end{tabular}

\section{E. Teknik Produksi Biodiesel}

Menurut Mishra dan Goswarni (2017) bahwa salah satu tahapan penting dalam produksi biodiesel adalah ekstraksi minyak. Pada proses ekstraksi minyak, minyak yang terkandung di dalam biji diekstraksi. Produk utama dari proses ini adalah minyak mentah dan produk sampingan seperti biji-bijian atau kernel cakes. Ada tiga metode umum untuk ekstraksi minyak:

1. Ekstraksi mekanis.

2. Ekstraksi pelarut.

3. Ekstraksi enzimatis. 
Metode mekanis (menggunakan alat pres atau expeller) merupakan metode yang paling konvensional. Dalam metode ini bahan yang digunakan adalah biji-bijian utuh, inti biji (kernel), atau campuran keduanya digunakan, akan tetapi yang sering digunakan adalah menggunakan biji-bijian utuh. Ekstraksi menggunakan metode mekanis menghasilkan minyak sekitar 68-80\% (Atabani, 2012). Sebaliknya, pada metode ekstraksi secara kimia, bahan utama yang digunakan hanya kernel (Achten dkk., 2008).

Pada teknik ekstraksi pelarut, ekstraksi minyak dari biji dilakukan dengan menggunakan cairan pelarut. Beberapa faktor mempengaruhi laju ekstraksi minyak (seperti ukuran partikel, jenis cairan pelarut yang dipilih, suhu, dan agitasi pelarut). Tiga teknik gunakan metode pelarut untuk ekstraksi minyak yaitu:

a. Ekstraksi air panas.

b. Ekstraksi soklet.

c. Teknik ultrasonik.

Teknik ekstraksi minyak yang paling menguntungkan adalah teknik enzimatis. Dalam proses ini, enzim yang sesuai digunakan untuk mengekstrak minyak dari sumber nabati. Protease alkali memberikan hasil yang lebih baik pada ekstraksi minyak enzimatis dalam larutan. Selain itu, pretreatment ultrasonik merupakan langkah yang tepat pada ekstraksi minyak dalam larutan (Atabani dkk., 2012; Achten dkk., 2008). Permasalahan yang paling umum terkait dengan minyak mentah yang bersumber dari minyak nabati yaitu memiliki viskositas tinggi, volatilitas rendah, dan karakter tak jenuh ganda (polyunsaturated). Permasalahan tersebut dapat diatasi dengan empat metode antara lain yaitu penggunaan langsung dan pencampuran (pengenceran), pirolisis, mikroemulsi, dan transesterifikasi (Atabani dkk., 2012; Srivastava dan Prasad, 2000; Balat dan Balat, 2008; Balat dan Balat, 2010; Lin dkk., 2011). 


\section{F. Evaluasi}

1. Jelaskan sejarah biodiesel!

2. Apa yang Anda ketahui tentang biodiesel?

3. Jelaskan perkembangan biodiesel di Indonesia?

4. Jelaskan teknik ekstraksi minyak yang Anda ketahui!

5. Jelaskan reaksi konversinya trigliserida menjadi biodiesel! 


\section{BAB II \\ KLASIFIKASI DAN \\ KARAKTERISTIK BIODIESEL}

\section{A. Capaian Pembelajaran}

Setelah mempelajari bab ini, diharapkan mahasiswa dapat mengetahui dan menjelaskan tentang klasifikasi biodiesel, kualitas biodiesel, dan karakteristik biodiesel.

\section{B. Klasifikasi Biodiesel}

Biodiesel merupakan sumber energi alternatif yang dapat diperbarui secara hayati dalam semua aspek seperti bahan baku, produk, dan produk sampingannya semua dapat diperbarui. Oleh karena itu, biodiesel sering disebut sebagai karbon netral. Biodiesel yang memiliki sifat biodegradable dan titik nyala yang tinggi membuatnya lebih aman saat terjadi insiden tabrakan maupun terjadi tumpahan. Teknologi saat ini memungkinkan produksi biodiesel dari minyak yang berasal dari tumbuhan (nabati) atau hewan. Di seluruh negara yang ada di dunia, minyak nabati dan sumber lemak lainnya telah digunakan sebagai bahan baku selama bertahun-tahun. Minyak yang berasal dari tumbuhan menghasilkan konversi biodiesel yang lebih baik dibandingkan minyak yang berasal dari sumber yang lain (Fukuda, dkk., 2001; Yusuf dkk., 2011).

Pada akhirnya akan ada kebutuhan bahan awal yang sesuai, yang dapat menghasilkan lipid dengan berkualitas tinggi untuk transesterifikasi dan produk biodiesel selanjutnya. Sumber bahan terdiri dari trigliserida yang mengandung tiga untai panjang asam lemak yang terikat pada molekul gliserin. Kandungan asam lemak dapat berbeda tergantung pada panjang rantai dan derajatnya ketidakjenuhan (unsaturation). Secara keseluruhan setiap bahan sumber minyak memiliki kandungan asam lemak yang berbeda pula (Behzadi dan Farid, 2007). Tabel 2.1 menunjukkan persentase komposisi asam lemak dalam minyak yang biasa digunakan untuk pembuatan biodiesel. 
Tabel 2.1 Komposisi asam lemak pada minyak dan lemak (Balasubramanian dan Steward, 2019)

\begin{tabular}{|l|l|l|l|l|l|l|l|l|l|l|}
\hline Minyak/Lemak & $12: 0$ & $14: 0$ & $16: 0$ & $18: 0$ & $18: 1$ & $18: 2$ & $18: 3$ & $20: 0$ & $20: 1$ & $22: 1$ \\
\hline Kacang Kedelai & - & - & 8 & 5 & 25 & 55 & 11 & - & - & - \\
\hline Jagung & - & 2 & 10 & 4 & $19-49$ & $34-62$ & - & - & - & - \\
\hline Kacang Tanah & - & - & 9 & $2-3$ & $50-65$ & $20-30$ & - & - & - & - \\
\hline Minyak Zaitun & - & - & 10 & $2-3$ & $73-84$ & $10-12$ & - & - & - & - \\
\hline Biji Kapas & - & $0-2$ & 23 & $1-2$ & $23-35$ & $40-50$ & - & - & - & - \\
\hline Mentega & - & $7-10$ & 25 & $10-13$ & $28-31$ & $1-2$ & $2-5$ & - & - & - \\
\hline Lemak Babi & - & $1-2$ & 30 & $12-18$ & $40-50$ & $7-13$ & $0-1$ & - & - & - \\
\hline Lemak Biji & - & $3-6$ & 26 & $20-25$ & $37-43$ & $2-3$ & - & - & - & - \\
\hline $\begin{array}{l}\text { Minyak } \\
\text { Rami }\end{array}$ & - & 6 & $2-4$ & $25-40$ & $35-40$ & $25-60$ & - & - & - \\
\hline $\begin{array}{l}\text { Pongamina } \\
\text { Pinnata }\end{array}$ & - & 2 & 6 & 8 & $45-71$ & $11-18$ & - & 4 & 11 & 5 \\
\hline $\begin{array}{l}\text { Minyak Kelapa } \\
\text { Minyak Kelapa }\end{array}$ & - & $17-21$ & 10 & $2-4$ & $5-10$ & $1-3$ & - & - & - & - \\
\hline $\begin{array}{l}\text { Sawit Inti } \\
\text { Minyak }\end{array}$ & - & 44 & 5 & 39 & 10 & - & - & - & - \\
\hline
\end{tabular}


Nomenklatur asam lemak pada Tabel 2.1 adalah sebagai berikut angka di sebelah kiri mewakili jumlah atom karbon dan angka setelah titik dua melambangkan jumlah ikatan rangkap dalam asam lemak. Berdasarkan jumlah atom karbon dan jumlah ikatan rangkap, setiap asam lemak memiliki titik beku yang berbeda, kemampuan untuk mempolimerisasi dan kandungan energi keseluruhan (Rustan dan Drevon, 2005). Komposisi asam lemak juga dapat mempengaruhi sifat fisik penting biodiesel seperti viskositas (fluiditas), titik penyalaan, dan mengeras pada suhu rendah. Derajat ketidakjenuhan juga mempengaruhi kinerja biodiesel yang dihasilkan oleh minyak nabati (Abbaszaadeh dkk., 2012; Ramos dkk., 2009; Ismail dan Ali, 2015). Tingkat kejenuhan keseluruhan minyak biodiesel diberikan pada Tabel 2.2

Tabel 2.2 Tingkat sifat asam lemak (saturasi/tingkat kejenuhan) dalam minyak biasa dan lemak

\begin{tabular}{|l|c|c|c|}
\hline \multicolumn{1}{|c|}{ Minyak } & Saturated(\%) & $\begin{array}{c}\text { Mono } \\
\text { Unsaturated(\%) }\end{array}$ & $\begin{array}{c}\text { Poly } \\
\text { Unsaturated(\%) }\end{array}$ \\
\hline Mentega & 63 & 26 & 4 \\
\hline Minyak Canola & 7 & 62 & 31 \\
\hline Minyak Kelapa & 90 & 6 & 54 \\
\hline Minyak Camelina & 10 & 33 & 12 \\
\hline Minyak Chufa & 20 & 67 & 59 \\
\hline Minyak Jagung & 13 & 24 & 11 \\
\hline Minyak Zaitun & 14 & 73 & 58 \\
\hline Minyak Kedelai & 16 & 23 & 32 \\
\hline Minyak Kacang & 17 & 46 & 21 \\
\hline Minyak Biji Kapas & 26 & 18 & 92 \\
\hline Lemak Ayam & 30 & 45 & 2 \\
\hline Lemak Babi & 39 & 45 & 66 \\
\hline $\begin{array}{l}\text { Minyak Kelapa } \\
\text { Sawit }\end{array}$ & 49 & 37 & 79 \\
\hline Minyak Inti Sawit & 81 & 11 & \\
\hline $\begin{array}{l}\text { Minyak Bunga } \\
\text { Matahari }\end{array}$ & 10 & 20 & \\
\hline Minyak Safflower & 7 & 14 & \\
\hline
\end{tabular}

${ }^{*}$ Catatan =Nilai dirata-ratakan. Nilai sebenarnya mungkin berbeda tergantung dari wilayah tempat tumbuhnya bahan, modifikasi genetik, dan metode ekstraksi. 
Minyak dengan jumlah lemak jenuh maksimum menghasilkan biodiesel dengan titik gel lebih rendah. Biodiesel yang berasal dari minyak dengan lebih banyak derajat ketidakjenuhan (unsaturation) akan teroksidasi lebih cepat daripada minyak dengan sedikit ketidakjenuhan (unsaturation). Contohnya biodiesel yang berasal dari minyak kenari, minyak poppy dan minyal biji rami mengalami degradasi relatif cepat (Ramos dkk., 2009).

Saat ini, biodiesel berasal dari minyak goreng bekerja dengan baik secara komparatif ke bahan sumber lainnya. Sebagian besar minyak ini mengandung satu atau dua ikatan rangkap per asam lemak. Hal ini memberikan umur simpan yang optimal untuk biodiesel dan sifat yang diinginkan (Behzadi dan Farid, 2007; Ismali dan Ali, 2015) Berdasarkan performanya, minyak kanola dilaporkan memiliki kinerja yang baik saat dikonversi ke biodiesel. Secara historis, hal ini menyebabkan terjadinya peningkatan biaya minyak kanola di pasar AS. Minyak zaitun juga menjadi salah satu pilihan sumber bahan baku untuk memproduksi biodiesel. Keuntungan minyak canola adalah dapat dimodifikasi secara genetik untuk menghasilkan peningkatan jumlah kandungan polyunsaturated daripada kandungan saturated-nya.

Minyak nabati terhidrogenasi tidak signifikan dalam produksi biodiesel karena menghasilkan bahan bakar dengan kualitas yang tidak diinginkan. Minyak goreng bekas, terutama yang mengandung asam lemak bebas tinggi sangat baik untuk produksi biodiesel (Pinto dkk., 2005; Abbaszaadeh dan Ghobadian, 2012; Yusuf dkk., 2011; Omidvarborna dkk., 2014; Allen dkk., 1999).

\section{Kualitas Biodiesel}

Peningkatan kualitas biodiesel saat ini sedang dikembangkan secara global. Ketika biodiesel diproduksi dari tanaman yang berbeda dengan berbagai daerah asal, maka akan menghasilkan sifat dan kualitas yang berbeda pula. Oleh karena itu, perlu adanya standarisasi kualitas biodiesel untuk memastikan kinerja mesin tanpa ada kendala (Atabani dkk., 2012; Balat dan Balat, 2010; Lin dkk., 